\title{
PENGARUH PROFITABILITAS, INVESMENT OPPORTUNITY SET, COST POLITIC TERHADAP KEBIJAKAN DEVIDEN TUNAI DENGAN LIKUIDITAS SEBAGAI VARIABEL MODERASI PADA PERUSAHAAN PLAT MERAH
}

\author{
Pramandyah Fitah Kusuma $^{1)}$, Endah Supeni Purwaningsih ${ }^{2)}$ \\ Universitas Wijaya Putra Surabaya \\ ${ }^{1}$ Email : pramandyahfitah@uwp.ac.id \\ ${ }^{2}$ Email : endahsupeni.uwp@gmail.com
}

\begin{abstract}
This study aims to determine whether the independent variables consisting of profitability as measured in Return on Investment, investment opportunity set as measured in the Market Book to Value of Equity, and Cost Politics as measured in Return on Assets affect the dependent variable, namely the cash dividend policy. measured in the Dividend Payout Ratio, and whether Liquidity as a moderating variable can affect the relationship, either simultaneously or partially. The approach used in this research is a quantitative approach, namely testing the theory through measuring the research variables with numbers and analyzing the data using statistical procedures. The research object uses state-owned companies (BUMN) listed on the Indonesia Stock Exchange during the study period, namely 2015-2018, where sampling is based on predetermined characteristics. The data used is secondary data obtained from the official IDX website, namely www.idx.co.id. The data were processed using the SPSS program using multiple regression and interaction regression testing tools.
\end{abstract}

Keywords: Return on Invesment, Market Book to Value of Equity, Cost Politic, Dividend Payout Ratio dan Current Ratio

\begin{abstract}
ABSTRAK
Penelitian ini bertujuan untuk mengetahui apakah variabel independen yang terdiri dari profitabilitas yang diukur dalam Return on Investment, investment oportunity set yang diukur dalam Market Book to Value of Equity, serta Cost Politic yang diukur dalam Return On Asset berpengaruh terhadap variabel dependen yaitu kebijakan dividen tunai yang diukur dalam Dividend Payout Ratio, dan apakah Likuiditas sebagai variable moderasi dapat mempengaruhi hubungan tersebut, baik secara simultan maupun parsial. Pendekatan yang digunakan dalam penelitian ini adalah pendekatan kuantitatif, yaitu pengujian teori melalui pengukuran variabel penelitian dengan angka dan melakukan analisis data dengan prosedur statistik. Obyek penelitian menggunakan perusahaan plat merah (BUMN) yang terdaftar di Bursa Efek Indonesia selama periode penelitian yaitu 2015-2018, dimana pengambilan sampel didasarkan pada karakteristik yang telah ditentukan. Data yang digunakan adalah data sekunder yang didapat dari situs resmi BEI yaitu www.idx.co.id. Data diolah dengan program SPSS menggunakan alat uji regresi berganda dan regresi interaksi.
\end{abstract}

Kata Kunci : Return on Invesment, Market Book to Value of Equity, Cost Politic, Dividend Payout Ratio dan Current Ratio 


\section{PENDAHULUAN}

Saat ini banyak sekali penawaran investasi baik yang dilakukan oleh perusahaan pemerintah maupun swasta dengan tingkat bunga return yang beragam. Karena investasi merupakan aktivitas penanaman modal pada suatu usaha yang bertujuan untuk mendapatkan keuntungan atas modal yang ditanamkan tersebut di masa yang akan datang, investasi ini dapat dilakukan dimana saja termasuk di dalam pasar modal.

Dalam penelitian ini, penulis tertarik untuk meneliti pengaruh profitabilitas, investment oppourtunity set, dan cost political terhadap kebijakan devident tunai dengan likuiditas sebagai variable moderasi pada perusahaan plat merah (BUMN) yg terdaftar di bursa efek. Karena bagi sebagian besar investor, penanaman modal untuk perusahaan plat merah lebih menjanjikan keuntungan yg besar dan stabil. Dalam pasar modal para investor dituntut untuk cermat dan bijak dalam mempertimbangkan dananya yang akan diinvestasikan, agar investor dapat memperoleh pendapatan atau tingkat pengembalian atas investasi (return) yang telah dilakukan terhadap suatu perusahaan baik berupa pendapatan deviden maupun berupa pendapatan yang diperoleh dari selisih harga jual saham dengan harga beli saham yang disebut capital gain seperti yang di harapkan. Bagi kebanyakan investor pendapatan dividen merupakan salah satu faktor penting yang menjadi bahan pertimbangan bagi investor, karena investor lebih menginginkan pembagian deviden dalam bentuk tunai dibanding dengan pendapatan yang diperoleh dalam bentuk capital gain. Sebab pembagian dividen dalam bentuk tunai membantu mengurangi ketidakpastian investor dalam aktivitas investasinya pada suatu perusahaan.

Menurut Suharli (2007), bagi para pemegang saham atau investor dividen kas merupakan tingkat pengembalian investasi kepemilikan saham yang diterbitkan oleh perusahaan tersebut. Bagi pihak manajemen, dividen kas merupakan arus kas keluar yang mengurangi kas perusahaan.

Karena faktor tersebut diatas kebijakan pembayaran dividen merupakan keputusan penting dalam bidang keuangan perusahaan, sebab tujuan utama perusahaan adalah meningkatkan laba perusahaan, kemakmuran pemegang sahamnya dan memaksimumkan nilai perusahaan. Pemilihan keputusan ini akan melibatkan dua pihak yang berkepentingan dan saling bertentangan yaitu kepentingan pemegang saham dengan dividennya dan kepentingan perusahaan atau manajemen dengan saldo laba yang akan digunakan sebagai dana investasi untuk ekspansi perusahaan.

Berkaitan dengan hal tersebut diatas,tidak jarang perusahaan dihadapkan pada kesulitan dalam pengambilan keputusan tentang kebijakan dividen yang diterapkan suatu perusahaan dalam pembagian dividen kepada pemegang saham. Dimana dalam hal ini kebijakan dividen merupakan keputusan untuk memutuskan berapa jumlah laba perusahaan yang digunakan untuk membayar dividen kas kepada pemegang saham dan berapa jumlah yang akan ditahan dalam bentuk laba ditahan untuk pembiayaan atau investasi di masa depan yang berguna bagi pertumbuhan dan perkembangan perusahaan dan berapa pengakuan laba yg harus ditunda untuk meminimalkan biaya politis

Ketika memutuskan berapa banyak laba yang didistribusikan kepada pemegang saham, perusahaan harus ingat bahwa tujuan perusahaan adalah memaksimumkan kemakmuran para pemegang saham. Maka semakin besar perusahaan menggunakan labanya untuk membayar dividen maka semakin kecil dana yang dapat digunakan untuk 
pembiayaan investasi dimasa depan, dimana pembiayaan ini akan meningkatkan pertumbuhan dan nilai perusahaan.

Untuk mengatasi masalah tersebut, maka digunakan perhitungan rasio yang dikenal sebagai Dividen Payout Ratio (DPR) yaitu presentase pendapatan yang akan dibayarkan kepada pemegang saham dalam bentuk dividen kas. Dimana semakin tinggi dividend payout ratio yang diterapkan suatu perusahaan, maka semakin kecil dana yang dapat dimanfaatkan untuk pembiayaan investasi yang berarti akan menghambat perkembangan dan pertumbuhan perusahaan. Dividend payout ratio dapat menggambarkan kebijakan dividen tunai yang diambil oleh perusahaan karena dengan melihat besarnya dividend payout ratio yang dimiliki perusahaan akan diketahui apakah perusahaan lebih memilih untuk membagikan kepada pemegang saham dalam bentuk dividen ataukah menggunakannya sebagai pembiayaan investasi di masa depan yang lebih menguntungkan bagi pertumbuhan perusahaan. Namun disisi lain, terutama pada perusahaan plat merah (BUMN) dengan cost politic yang tinggi akan cenderung menurunkan labanya yang tentu saja akan mempengaruhi besarnya Dividend Payout Ratio.

Oleh karena itu perlu bagi manajemen perusahaan untuk mempertimbangkan keputusan penggunaan laba perusahaan dengan mempertimbangkan faktor-faktor yang menurut perusahaan dapat mempengaruhi kebijakan dividen dalam perusahaan tersebut. Faktor-faktor yang diduga mempengaruhi kebijakan dividen dalam penelitian ini adalah profitabilitas, Investment Opotunity Set ,dan Cost Politic.

Profitabilitas adalah kemampuan perusahaan untuk menghasilkan keuntungan dengan tingkat penjualan, asset dan modal saham tertentu.
Sedangkan proporsi laba bersih per satu lembar saham biasa yang dibayar dalam bentuk dividen disebut Dividend Payout Ratio. Oleh karena dividen diambil dari laba bersih yang diperoleh perusahaan, maka laba tersebut akan mempengaruhi besarnya dividend payout ratio. Investor yang mengharapkan memperoleh capital gain akan lebih menyukai angka rasio ini yang rendah. Sebaliknya investor yang menyukai dividen, ingin angka rasio ini yang lebih tinggi (Prastowo, 2005).

Investasi merupakan kegiatan yang bertujuan untuk memaksimumkan kekayaan bagi pertumbuhan dan perkembangan perusahaan. Setiap entitas bisnis dalam menjalankan usahanya selalu memiliki harapan untuk tetap going concern. Pertumbuhan yang selalu meningkat serta bertambahnya nilai aset perusahaan yang melambangkan banwa perusahaan ini memiliki nilai yang cukup tinggi di pasar. Namun hal tersebut akan diperoleh oleh perusahaan yang memiliki peluang atau kesempatan investasi (investment oportunity set), dimana hal itu memerlukan dana investasi yang cukup tinggi. Kesempatan investasi itu dapat diproksikan dengan perbandingan nilai pasar ekuitas terhadap nilai buku ekuitas yang disebut dengan market to book value of equity.Dimana besar kecilnya kesempatan investasi (investment oportunity set) akan mempengaruhi kebijakan dividen tunai. Perusahaan yang memiliki peluang atau keperluan investasi lebih banyak akan memiliki dividend payout ratio lebih rendah.

Fenomena yang ingin diungkap pada penelitian ini, cost politic muncul biasanya jika ada kontra kepentingan antara pihak pemerintah yang mengeluarkan peraturan dengan perusahaan plat merah yang menjadi objek dari perubahan peraturan tersebut. Perusahaan mengeluarkan biaya politis berupa pajak, subsidi pemerintah, biaya tuntutan buruh, subsidi pemerintah dan lain sebagainya 
(Sarwindah dan Afrieyenti, 2015). Dalam hal ini ukuran perusahaan juga mempengaruhi cost politic yg ada, semakin besar perusahaan, maka akan semakin besar pula cost politic yg harus dikeluarkan oleh perusahaan, dan hal ini otomatis akan mempengaruhi laba yg diperoleh perusahaan, dan pada akhirnya juga berpengaruh terhadap pembagian devident tunai.

Likuiditas merupakan kemampuan perusahaan untuk memenuhi kewajiban finansialnya yang segera harus dipenuhi. Posisi kas atau likuiditas merupakan pertimbangan yang dapat mengubah keputusan dividen yang dipengaruhi oleh profitabilitas, investment oportunity set dan cost Politic. Semakin besar likuiditas yang dimiliki perusahaan maka semakin besar kemampuan kas perusahaan tersebut dan semakin besar pula dividen yang dapat dibagikan kepada para pemegang saham. jadi walaupun profitabilitas rendah ,investment oportunity set yang dimiliki perusahaan tinggi, ataupun cost politic juga tinggi, tapi jika tingkat likuiditas tinggi maka nilai pembagian dividen akan naik.

Menurut Syifa Fauzia (2018) political cost tidak memiliki pengaruh terhadap konservatisme akuntansi. Laporan keuangan merupakan sarana perusahaan dalam menyajikan laporan keuangan perusahaan, posisi keuangan dan perubahannya serta kinerja perusahaan. Setiap perusahaan akan berusaha menyajikan laporan keuangan yang sesuai dengan standart akuntasi yang berlaku dan memaksimalkan nilai perusahaan. Laporan keuangan ini diharapkan dapat menarik minat investor ataupun pihak eksternal lainnya dalam menilai kemampuan perusahaan dalam menghasilkan laba ( Jayanti dan Sapri, 2016). Dalam hal ini terutama bagi perusahaan plat merah (BUMN). Agar Laporan Keuangan yang dihasilkan memiliki kualitas yang baik, maka dalam menyusun Laporan Keuangan tersebut dibutuhkan konsep kehati-hatian atau konservatisme akuntansi, menurut Watts (2003) Konservatisme akuntansi dapat dikatakan sebagai sifat kehati-hatian dalam menyusun laporan keuangan yang dilakukan perusahaan, dimana perusahaan segera mengakui kerugian dan hutang namun tidak terburu-buru dalam mengakui aktiva dan laba. Namun disisi lain kebijakan pembagian dividend tunai sangat dipengaruhi oleh laba yang dihasilkan perusahaan pada periode tertentu. Hal ini yang mendorong penulis untuk meneliti pengaruh cost political terhadap kebijakan dividend tunai, karena cost political terhadapa perusahaan plat merah sangat tinggi sekali, hal ini terkait dengan regulasi pemerintah.

\section{Kajian Literatur Kebijakan Dividen Tunai}

Dalam manajemen keuangan terdapat tiga kebijakan diantaranya kebijakan investasi (penggunaan dana), kebijakan pendanaan (memperoleh dana) dan kebijakan dividen (pembagian laba). Manager keuangan memiliki dua kegiatan utama yang merupakan fungsi keuangan yaitu mencari dana dan menggunakan aset perusahaan. Mencari dana melalui dua sumber yaitu sumber dana eksternal dan sumber dana internal. Sumber dana eksternal adalah sumber dana yang bukan dari hasil kegiatan perusahaan, diantaranya dana dari pasar uang berupa hutang, saham, diskon dari pembelian, penghematan atau pembebasan pajak, subsidi dan lain-lain. Sedangkan sumber dana internal adalah sumber dana yang berasal dari hasil kegiatan operasi perusahaan secara langsung, berasal dari depresiasi saldo dan laba yang diperoleh perusahaan.

Kebijakan dividen perusahaan juga harus dipandang sebagai bagian dari keputusan pendanaan perusahaan. Ratio pembayaran dividend (dividend payout ratio) menetapkan jumlah laba yang 
dapat ditahan dalam perusahaan. Semakin banyak jumalh laba yang dapat ditahan dalam perusahaan berarti semakin sedikit jumlah uang yang akan tersedia untuk pembayaran dividen. Oleh karena itu, nilai dari dividend yang dibayarkan kepada para pemegang saham harus dipertimbangkan dengan biaya peluang dari saldo laba yang hilang karena memilih pendanaan melalui ekuitas

Menurut Arthur J. Kweon dkk (2000) dalam Palino (2012) dalam bukunya "Basic Financial Management" kebijakan dividen perusahaan meliputi dua komponen dasar. Pertama, rasio pembayaran dividen menunjukkan jumlah dividen yang dibayarkan relatif terhadap pendapatan perusahaan, kedua adalah stabilitas dividen sepanjang waktu. Dengan mengasumsikan manajemen sudah memutuskan berapa banyak dana yang diinvestasikan dan memilih panduan utang-modalnya untuk mendanai investasi, maka keputusan untuk membayar dividen besar yang berarti akan menahan sedikit laba, yang berakibat membuat ketergantungan yang lebih besar pada pendanaan modal eksternal. Begitu pula sebaliknya.

\section{Rasio Profitabilitas}

Rasio yang mengukur kemampuan perusahaan untuk menghasilkan laba dengan menggunakan sumber-sumber yang dimilki perusahaan, seperti aktiva, modal atau penjualan perusahaan. Dalam rasio profitabilitas terdapat beberapa rasio untuk mengukur profit yang dihasilkan perusahaan yaitu Return on Asset, Return on Investment dan Return on Equity. Rasio yang digunakan dalam penelitian ini untuk mewakili tingkat profitabilitas perusahaan adalah Return on Assets (ROA). ROA menunjukkan kemampuan perusahaan dengan menggunakan seluruh aktiva operasi yang dimiliki untuk menghasilkan laba setelah pajak. ROA merupakan perbandingan antara laba bersih setelah pajak dengan total aktiva operasi. Rasio ini penting bagi pihak manajemen untuk mengevaluasi efektivitas dan efisiensi manajemen perusahaan dalam mengelola seluruh aktiva operasi perusahaan. Semakin besar ROA maka semakin efisien penggunaan aktiva perusahaan atau dengan kata lain dengan jumlah aktiva yang sama bisa dihasilkan laba yang lebih besar. Dengan laba yang besar maka secara teoritis kinerja perusahaan juga meningkat, sehingga harga saham perusahaan pun juga akan meningkat (Sudana, 2011).

\section{Investment oportunity set (IOS)}

Menurut Tjandra (2005), investment oportunity set (IOS) adalah set kesempatan investasi yang merupakan pilihan investasi di masa yang akan datang dan mencerminkan adanya pertumbuhan aktiva dan ekuitas. Menurut Putri (2011), istilah investment oportunity set (IOS) pertama kali ditemukan oleh Myers (1977), yang memandang nilai suatu perusahaan sebagai suatu kombinasi assets in place (aset yang dimiliki) dengan investment options (pilihan investasi) masa depan. Assets in place yang dinilai secara independen dari kesempatan investasi perusahaan di masa mendatang dan pilihan pertumbuhan yang dinilai atas dasar keputusan investasi discretionary (yang dipilih sesuai kebijakan) perusahaan di masa mendatang. Pilihan investasi merupakan suatu kesempatan untuk berkembang, namun seringkali perusahaan tidak selalu dapat melaksanakan semua kesempatan investasi di masa mendatang. Bagi perusahaan yang tidak dapat menggunakan kesempatan investasi tersebut akan mengalami suatu pengeluaran yang lebih tinggi dibandingkan nilai kesempatan yang hilang. Nilai kesempatan investasi merupakan nilai sekarang dari pilihan-pilihan peru- 
sahaan untuk membuat investasi di masa mendatang.

Kole (1991) dalam Nopratiwi (2004) menyatakan bahwa nilai IOS bergantung pada pengeluaran-pengeluaran yang ditetapkan manajemen untuk masa yang akan datang (future discretionary expenditure) yang pada saat ini merupakan pilihan-pilihan investasi yang diharapkan akan menghasilkan return yang lebih besar dari biaya modal (cost of equity) yang dikeluarkan dan dapat menghasilkan keuntungan.

Kallapur dan Trombley (2007) dalam Putri (2011) menyatakan bahwa kesempatan investasi perusahaan merupakan komponen penting dari nilai pasar. Hal ini disebabkan karena nilai masa depan dari kesempatan investasi yang tinggi akan menaikkan nilai pasar perusahaan. Namun IOS atau set kesempatan investasi perusahaan mempengaruhi cara pandang manajer, pemilik, investor dan kreditur terhadap perusahaan. Dengan demikian IOS bersifat tidak dapat diobservasi sehingga perlu dipilih suatu proksi yang dapat dihubungkan dengan variabel lain dalam perusahaan, misalnya variabel kebijakan, variabel pertumbuhan dan lain-lain. Dari berbagai penelitian tentang IOS dapat dibuktikan bahwa IOS memiliki hubungan dengan berbagai variabel kebijakan perusahaan (Nopratiwi, 2004).

Menurut uraian-uraian tersebut penulis mengambil pemikiran bahwa IOS memang menggambarkan peluang investasi di masa depan tapi hal tersebut akan berjalan jika manajemen perusahaan dapat menganalisa dan mengeksploitasi keadaan sehingga dapat diperoleh pilihan investasi yang memiliki keuntungan di masa yang akan datang bagi perusahaan.

\section{Hubungan profitabilitas dengan kebijakan dividen tunai Menurut Khasanah profitabilitas berpengaruh terhadap}

kebijakan dividen, karena dividen adalah sebagian dari laba bersih yang diperoleh perusahaan, oleh karena itu dividen akan dibagikan apabila perusahaan memperoleh keuntungan. Oleh karena itu dividen yang diambilkan dari keuntungan bersih (setelah dikurangi pajak) akan mempengaruhi dividend payout ratio. Makin tinggi tingkat keuntungan perusahaan maka makin tinggi pula tingkat dividen yang dibagikan.

Dalam penelitian ini profitabilitas yang diproksikan dalam ROA diperoleh dari laba bersih dibagi total aktiva perusahaan untuk menghitung rasio laba bersih yang diperoleh dengan aktiva yang digunakan, sehingga semakin tinggi nilai ROA berarti semakin tinggi laba bersih yang diperoleh perusahaan. Sedangkan kebijakan dividen diproksikan menggunakan DPR yang dihitung dengan perbandingan dividen kas tahunan dengan pendapatan dividen per lembar dari laba bersih perusahaan. Rasio ini digunakan untuk mengetahui berapa presentase dividen yang diperoleh pemegang saham dengan jumlah keseluruhan laba bersih yang bisa diperoleh pemegang saham tanpa adanya laba yang ditahan oleh perusahaan. Maka besar kecilnya dividen yang dibagi tergantung pada besar kecilnya laba yang diperoleh perusahaan. Semakin tinggi laba berdih yang diperoleh perusahaan maka semakin tinggi jumlah pembagian dividen, dan sebaliknya.

\section{Hubungan IOS dengan kebijakan dividen tunai}

Menurut Putri (2011), kebijakan pembayaran dividen mempunyai pengaruh bagi pemegang saham dan perusahaan yang membayar dividen. Para pemegang saham umumnya menginginkan pembagian dividen yang relatif stabil karena hal tersebut akan mengurangi ketidakpastian akan hasil yang diharapkan dari investasi yang mereka lakukan dan juga dapat mening- 
katkan kepercayaan pemegang saham terhadap perusahaan sehingga nilai saham juga dapat meningkat. Bagi perusahaan, pilihan untuk membagikan laba dalam bentuk dividen akan mengurangi sumber dana internalnya, sebaliknya jika perusahaan menahan labanya dalam bentuk laba ditahan maka kemampuan pembentukan dana internalnya akan semakin besar yang dapat digunakan untuk membiayai aktivitas perusahaan sehingga mengurangi ketergantungan perusahaan terhadap dana eksternal dan sekaligus akan memperkecil resiko perusahaan.

Dalam penelitian ini IOS diproksikan dalam MBVE yang dihitung dengan perbandingan antara nilai pasar ekuitas (perkalian jumlah lembar saham beredar dikali harga penutupan saham) dengan nilai buku ekuitas, yang menggambarkan kemampuan perusahaan mengelola ekuitas untuk menghasilkan return yang melebihi nilai buku ekuitas perusahaan. Jika nilai pasar lebih tinggi dibanding dengan nilai buku ekuitas, maka mencerminkan bahwa perusahaan memiliki tingkat pertumbuhan dan prospek yang baik di masa depan. Maka perusahaan tersebut memiliki pilihan investasi di masa yang akan datang. Pilihan investasi tersebut dapat menjadi kesempatan investasi jika perusahaan dapat menganalisa dan mengeksploitasi pilihan investasi tersebut. Jadi kesempatan investasi yang akan menghasilkan keuntungan di masa depan bergantung pada keputusan yang diambil perusahaan.

\section{Hubungan Cost Politic Dengan Kebijakan Divident Tunai \\ Cost Politic adalah biaya yang dibebankan oleh pemerintah atau pemegang regulator kepada perusahaan BUMN, yang mempunyai keuntungan yang tinggi, dan hal ini otomatis menarik minat konsumen, media dan juga calon investor. Faktor inilah yang pada}

akhirnya menimbulkan tekanan politik, sehingga perusahaan akan dibebankan dengan peraturan pajak yang baru atau peraturan-peraturan yang lain. Adanya penambahan biaya politic seperti misalnya biaya demo buruh, CSR (Coorporate Social Responbility) secara otomatis akan berdampak terhadap besar kecilnya laba yang dihasilkan oleh perusahaan, sementara di sisi lain pihak manajement (agent) dituntut untuk dapat memaksimumkan kesejahteraan para pemegang saham disamping juga untuk meningkatkan pertumbuhan perusahaan. Atas dasar inilah, banyak perusahaan BUMN untuk mengurangi political cost, karena pemerintah selalu mengawasinya. Dengan cara menunda pengakuan laba . Pihak management berusaha memaksimalkan kepentingannya dan menunjukkan hasil kinerjanya melalui laporan keuangan yang konservatisme. Pada tingkat cost politic yang tinggi, perusahaan cenderung membayar dividend yang rendah, karena laba yang dihasilkan oleh perusahaan juga rendah. Dengan demikian menurut logika maka cost politic mempunyai pengaruh yang negative terhadap kebijakan dividend tunai.

\section{Hubungan likuiditas dengan profitabilitas ,IOS dan Cost Politic terhadap kebijakan dividen tunai}

Istilah likuiditas menunjukkan kemampuan perusahaan memenuhi kewajiban - kewajiban keuangannya dalam jangka waktu pendek atau yang segera harus dibayar. Alat pemenuhan kewajiban ini berasal dari unsur-unsur aktiva yang bersifat likuid, yakni aktiva lancar dengan perputaran kurang dari satu tahun, karena lebih mudah dicairkan daripada aktiva tetap yang perputarannya lebih dari satu tahun (Moeljadi, 2007).

Menurut Moeljadi (2007), likuiditas ditekankan pada kemampuan membayar, bukan kekuatan membayar. Perusahaan yang likuid adalah perusahaan yang 
mempunyai kekuatan besar untuk membayar, sehingga mampu memenuhi kewajiban finansialnya yang segera jatuh tempo. Meskipun perusahaan mempunyai kekuatan membayar yang besar, namun jika pada saat harus memenuhi kewajiban yang segera jatuh tempo ternyata tidak mampu memenuhinya, maka perusahaan tersebut dikatakan tidak likuid. Dalam penelitian ini likuiditas digunakan sebagai variabel moderasi karena dengan adanya tingkat likuiditas yang tinggi maka pembayaran dividen yang bergantung pada laba bersih ,kesempatan investasi dan biaya politik perusahaan akan lebih terjamin. Dengan variabel moderasi likuiditas penulis ingin mengetahui bagaimana kebijakan dividen pada perusahaan, akan menjadi semakin kuat atau semakin melemah. Harapan penulis jika profitabilitas tinggi, kesempatan investasi dan biaya politik yang rendah serta didukung dengan kemampuan

\section{METODE PENELITIAN}

\section{Populasi dan Sampel}

Populasi dari penelitian ini adalah perusahaan BUMN yang terdaftar di Bursa Efek Indonesia dan melakukan pembagian dividen tunai selama periode 2015 - 2018. Pemilihan sampel dalam penelitian ini menggunakan metode purposive sampling yaitu pemilihan sampel berdasarkan penilaian terhadap beberapa karakteristik anggota sampel yang disesuaikan dengan tujuan penelitian.

Karakteristik perusahaan yang dijadikan sampel dalam penelitian ini adalah :

1. Perusahaan BUMN yang terdaftar di BEI dan tidak keluar (delisting) selama periode 2015 - 2018 .

2. Perusahaan BUMN yang mengeluarkan laporan keuangan beserta informasi yang diperlukan dalam penelitian secara lengkap selama periode tahun 2015 - 2018
3. Perusahaan BUMN yang melakukan pembagian dividen tunai secara berturut-turut pada saat periode penelitian mulai dari tahun 2015 2018.

\section{Definisi Operasional Variabel}

1. Variabel independen (bebas)

(a) Return on Investment

Profitabilitas sebagai variabel independen diproksikan dalam ROI yang merupakan salah satu dari kelompok rasio profitabilitas yang digunakan untuk mengukur kemampuan perusahaan menghasilkan profit. Dalam kelompok rasio profitabilitas terdapat ROA, ROI dan ROE. Alasan mengapa konsep ROI digunakan dalam penelitian ini adalah bahwa ROI memberikan gambaran yang signifikan terhadap tingkat pengembangan aktiva operasi seluruh perusahaan. Sebab rasio ini menunjukkan laba atas seluruh dana atau kekayaan perusahaan yang diinvestasikan.

$$
\text { ROI }=\frac{\text { Laba Bersih setelah Pajak }}{\text { Total Aktiva Operasi }}
$$

(b)Market to Book Value of Equity (MBVE)

Investment opportunity set sebagai variabel independen kedua diproksikan dalam MBVE, yang merupakan rasio nilai buku ekuitas terhadap nilai pasar. Berdasarkan penelitian-penelitian sebelumnya, proksi yang paling banyak digunakan dalam memproksikan IOS yaitu MBVE dan MBVA. Dalam penelitian ini menggunakan MBVE karena dalam penelitian ini mengasumsiakn bahwa dana investasi pada umumnya diambil dari laba ditahan yang merupakan bagian dari ekuitas, maka perbandingan nilai pasar dan nilai buku ekuitas dianggap lebih 
cocok. Formula yang digunakan dalam MBVE adalah sebagai berikut

MBVE $=\frac{\text { Lembar saham beredar } x \text { Hargapemutupan saham }}{\text { Total ekuitas }}$

(c) Return To Asset (ROA)

Cost Politic sebagai variabel independen ketiga diproksikan dalam Return To Asset (ROA). Melalui ROA, investor dapat memperoleh gambaran secara jelas tentang tingkat pengembalian terhadap investasi yang telah dilakukannya pada suatu perusahaan BUMN tersebut. Di dalam formula perhitungan ROA memiliki makna menggunakan seluruh aktiva operasi yang dimiliki untuk menghasilkan laba setelah pajak (Sudana, 2011), dengan formula sebagai berikut :

$\mathrm{ROA}=\frac{\text { Laba bersih setelah pajak }}{\text { Total Asset }} \times 100 \%$

2. Variabel dependen (terikat)

Devidend Payout Ratio adalah salah satu rasio keuangan dari kelompok rasio pasar atau rasio investasi yang mengukur kemampuan perusahaan dalam membayar dividen kepada pemegang saham. Dalam penelitian ini DPR digunakan untuk memproksikan kebijakan dividen tunai yang merupakan variabel dependen yang dipengaruhi oleh variabel independen. Formula yang digunakan adalah sebagai berikut :

$$
D P R=\frac{\text { Deviden per lembar saham biasa }}{\text { Earning Per Share }(E P S)}
$$

3. Variabel moderasi

Variabel moderasi dalam penelitian ini adalah likuiditas yang diproksikan dalam current ratio yang merupakan salah satu rasio keuangan dari kelompok rasio likuiditas.
Dalam kelompok rasio likuiditas terdapat current ratio dan quick ratio. Alasan digunakannya current ratio dalam penelitian ini adalah karena dalam current ratio, persediaan dan persekot biaya diperhitungkan dalam aktiva lancar dan merupakan total keseluruhan akiva lancar dibagi dengan hutang lancar. Formula yang digunakan untuk mengukur variable ini adalah :

Cash Ratio $=$ kas $:$ Hutang Lancar

\section{Teknik Analisa Data}

Dalam penelitian ini, penulis menggunakan regresi berganda (Multiple Regression) untuk menguji pengaruh variabel independen terhadap variabel dependen dan regresi interaksi untuk menguji pengaruh variabel moderasi pada hubungan antara variabel independen dengan dependen. Variabel moderasi sebenarnya adalah variabel independen yang mempengaruhi hubungan variabel independen lainnya dengan variabel dependen. Teknik pengolahan data dilakukan dengan menggunakan program SPSS (Statistical Package for Social Sciences) versi 16.0.

Tahap-tahap yang dilakukan untuk menganalisa data guna menguji hipotesis adalah :

1. Menghitung variabel-variabel yang digunakan dalam pengujian antara lain variabel ROA, MBVE, ROI ,CR dan DPR.

2. Mentabulasi data yang diperlukan dalam rangka pengolahan data lebih lanjut dengan menggunakan program komputer SPSS.

3. Pengujian Hipotesis

Analisis data akan menghasilkan model penelitian yang akan diuji dengan regresi berganda dan regresi interaksi, dimana sebelumnya akan dilakukan uji deskriptif, uji asumsi klasik kemudian baru akan dilakukan uji hipotesis. 


\section{HASIL DAN PEMBAHASAN}

\section{Uji Hipotesis}

Uji hipotesis dilakukan dengan menggunakan dua jenis regresi, yaitu regresi linier berganda dan regresi interaksi. Persamaan regresi dapat dilihat dari tabel hasil uji coefficients yang didapat dari output SPSS terhadap variabel-variabel penelitian.

Tabel 1. Hasil Analisis Regresi Coefficients $^{\mathrm{a}}$

\begin{tabular}{|c|c|c|c|c|c|c|c|}
\hline \multirow[t]{2}{*}{ Model } & \multicolumn{2}{|c|}{$\begin{array}{l}\text { Unstandardized } \\
\text { Coefficients }\end{array}$} & \multirow{2}{*}{\begin{tabular}{|c|}
$\begin{array}{c}\text { Standardized } \\
\text { Coefficients }\end{array}$ \\
Beta \\
\end{tabular}} & \multirow[t]{2}{*}{$t$} & \multirow[t]{2}{*}{ Sig. } & \multicolumn{2}{|c|}{ Collinearity Statisitics } \\
\hline & $B$ & Std. Error & & & & Tolerance & $V \mid F$ \\
\hline (Constant) & 65,769 & 49,781 & & 1,321 & 197 & & \\
\hline ROI & $-7,230$ & 7,288 &,- 504 & -992 & 329 & , 116 & 8,612 \\
\hline MBVE &, 001 & ,006 & , 102 & 221 & 826 & , 142 & 7,023 \\
\hline ROA & 21,767 & 15,377 &, 952 & 1,416 & , 168 & 066 & 15,090 \\
\hline MODERATORCRROI & ,091 & , 059 &, 983 & 1,558 &, 130 & ,075 & 13,288 \\
\hline MODERATOR CR MBVE & $\begin{array}{r}-3,764 E- \\
006\end{array}$ & ,000, & ;091 & $-; 172$ & 864 & ,107 & 9,305 \\
\hline MODERTATOR CR ROA & -223 & , 124 & $-1,453$ & $-1,799$ &, 082 & 046 & 21,729 \\
\hline
\end{tabular}

Uji T :

Pada model 2 secara parsial semua variabel ROI, MBVE dan ROA yang dimoderasi $\mathrm{CR}$ tidak berpengaruh signifikan karena nilai signifikansi lebih dari 0,05 yaitu X1X4 sebesar 0,130,

Pada X2X4 sebesar 0,864 dan pada X3X4 sebesar 0, 082

Berdasarkan pada tabel 1. diatas, terlihat bahwa konstanta a sebesar 0,407 untuk persamaan (1) dan 0,312 untuk persamaan (2). Nilai konstansta dan koefisien regresi yang ada dalam tabel 4.8 dimasukkan dalam persamaan berikut ini :

$\mathrm{Y}=\mathrm{a}+\mathrm{b} 1 \mathrm{X} 1+\mathrm{b} 2 \mathrm{X} 2+\mathrm{b} 3 \mathrm{X} 3+\mathrm{e}$

Sehingga, persamaan regresinya menjadi

Persamaan Regresi Model 1:

$\mathrm{Y}=59,558+0,217 \mathrm{ROI}-0,025 \mathrm{MBVE}-$ $0,610 \mathrm{ROA}+\mathrm{e}$

Model persamaan (1) dapat dijelaskan sebagai berikut :

(a) Pada saat variabel independen (ROI, MBVE dan ROA) dalam keadaan konstan maka Y (DPR) sebesar 59,558 satuan. (b) Koefisien regresi ROI adalah sebesar 0,217 yang berarti bahwa setiap peningkatan ROI sebesar $1 \%$ maka DPR akan meningkat sebesar $21,7 \%$ dan sebaliknya dengan asumsi variabel lain konstan.

(c) Koefisien regresi MBVE sebesar 0,025 yang berarti bahwa setiap peningkatan MBVE sebesar 1\% akan menurunkan DPR 2,5\% dan sebaliknya dengan asumsi variabel lain konstan.

(d) Koefisien regresi ROA sebesar 0,610 yang berarti bahwa setiap peningkatan ROA sebesar $1 \%$ akan menurunkan DPR $61 \%$ dan sebaliknya dengan asumsi variabel lain konstan.

Persamaan Regresi Model 2:

$\mathrm{Y}=\mathrm{a}+\mathrm{b} 1 \mathrm{X} 1+\mathrm{b} 2 \mathrm{X} 2+\mathrm{b} 3 \mathrm{X} 1 \mathrm{X} 3$ $+b 4 X 2 \times 3+e \ldots \ldots \ldots \ldots \ldots . . .(2)$

Sehingga, persamaan regresinya menjadi :

$$
\begin{aligned}
\mathrm{Y}= & 65,769-0,54 \mathrm{ROI}+0,102 \mathrm{MBVE}+ \\
& \text { 0,962ROA + 0,983CR ROI - } \\
& \text { 0,09CR MBVE }-1,799 \mathrm{CR} \mathrm{ROA}+\mathrm{e}
\end{aligned}
$$

Model persamaan (2) dapat dijelaskan sebagai berikut :

(a) Pada saat variabel independen (ROA, MBVE) dan variabel moderator (CR.ROA yang mempengaruhi hubungan ROA dan DPR serta CR.MBVE yang mempengaruhi hubungan MBVE dengan DPR) dalam keadaan konstan maka Y (DPR) sebesar 65,769 satuan.

(b) Koefisien regresi ROI adalah $-0,54$ yang berarti bahwa setiap peningkatan ROI sebesar $1 \%$ maka DPR akan turun sebesar $54 \%$ dan sebaliknya dengan asumsi variabel lain kostan

(c) Koefisien regresi MBVE adalah 0,102 yang berarti bahwa setiap peningkatan MBVE sebesar $1 \%$ meningkatkan DPR sebesar 10,2\% dan sebaliknya dengan asumsi variabel lain kostan. 
(d) Koefisien regresi ROA adalah 0,692 yang berarti bahwa setiap peningkatan ROA sebesar $1 \%$ maka DPR naik sebesar $69,2 \%$ dan sebaliknya dengan asumsi variabel lain kostan.

(e) Koefisien regresi variabel moderator (CR.ROI) adalah 0,983 yang berarti bahwa setiap peningkatan variabel moderasi (CR) sebesar $1 \%$ akan meningkatkan DPR sebesar 98,3\% dan sebaliknya dengan asumsi ROI konstan.

(f) Koefisien regresi variabel moderator (CR.MBVE) adalah 0,09 yang berarti bahwa setiap peningkatan variabel moderasi (CR) sebesar $1 \%$ akan meningkatkanDPR sebesar 9\% dan sebaliknya dengan asumsi MBVE konstan.

(g) Koefisien regresi variabel moderator (CR.ROA) adalah -1,799 yang berarti bahwa setiap peningkatan variabel moderasi (CR) sebesar $1 \%$ akan menurunkan DPR sebesar $179,9 \%$ dan sebaliknya dengan asumsi ROA konstan.

\section{Uji hipotesis ke-1(a) atau H1(a)}

Hipotesis ke-1(a) menyatakan bahwa profitabilitas, investment oportunity set dan cost politic tidak mempengaruhi kebijakan dividen tunai. Berdasarkan hasil perhitungan uji $\mathrm{F}$ yang ditunjukkan pada tabel 2, diketahui bahwa model atau persamaan ke-1 memiliki nilai $F$ sebesar 0,291 dengan tingkat signifikansi sebesar 0,831 yang lebih besar dibanding 0,05 yang merupakan angka derajat kepercayaan. Maka dapat disimpulkan bahwa Ha ditolak, yang berarti secara simultan atau bersama-sama tidak terdapat pengaruh yang signifikan antara profitabilitas, investment oportunity set dan cost politic terhadap kebijakan dividen tunai.
Tabel 2. Hasil Perhitungan Uji F (Secara Simultan)

ANOVA $^{a}$

\begin{tabular}{|c|c|c|c|c|c|c|}
\hline \multicolumn{2}{|c|}{ Model } & Sum of Squares & $d f$ & Mean Square & $\mathrm{F}$ & Sig. \\
\hline \multirow{3}{*}{1} & Regression & 10186,271 & 3 & 3395,424 & ,291 &, $831^{b}$ \\
\hline & Residual & 372974,587 & 32 & 11655,456 & & \\
\hline & Total & 383160,858 & 35 & & & \\
\hline
\end{tabular}

a. Dependent Variable: DPR

b. Predictors: (Constant), ROA, MBVE, ROI

\section{Uji hipotesis ke-1(b)atau H1(b)}

Hipotesis ke-1(b) menyatakan bahwa profitabilitas tidak mempengaruhi kebijakan dividen tunai. Berdasarkan hasil perhitungan uji $\mathrm{t}$ yang ditunjukkan pada tabel 4.12, diketahui bahwa ROI memiliki nilai $\mathrm{t}$ hitung sebesar 0,847 dengan tingkat signifikasi 0,403 , yang lebih besar dibanding 0,05. Maka dapat disimpulkan bahwa Ha ditolak, yang berarti secara parsial tidak terdapat pengaruh yang signifikan antara profitabilitas terhadap kebijakan dividen tunai.

\section{Uji hipotesis ke-1(c) atau H1(c)}

Hipotesis ke-1(c) menyatakan bahwa investment oportunity set mempengaruhi kebijakan dividen tunai. Berdasarkan hasil perhitungan uji t yang ditunjukkan pada tabel 3, diketahui bahwa MBVE memiliki nilai $t$ hitung sebesar $-0,139$ dengan tingkat signifikasi 0,839 , yang lebih besar dibanding 0,05. Maka dapat disimpulkan bahwa $\mathrm{Ha}$ ditolak, yang berarti secara parsial tidak terdapat pengaruh yang signifikan antara investment oportunity set terhadap kebijakan dividen tunai.

Tabel 3. Hasil Perhitungan Uji T (Secara

$$
\text { Parsial) }
$$

\begin{tabular}{|c|c|c|c|c|c|c|c|}
\hline \multicolumn{8}{|c|}{ Coefficients $^{\mathrm{a}}$} \\
\hline \multirow[t]{2}{*}{ odel } & \multicolumn{2}{|c|}{$\begin{array}{l}\text { Unstandardized } \\
\text { Coefficients }\end{array}$} & \multirow{2}{*}{\begin{tabular}{|c}
$\begin{array}{c}\text { Standardized } \\
\text { Coefficients }\end{array}$ \\
Beta
\end{tabular}} & \multirow[t]{2}{*}{$t$} & \multirow[t]{2}{*}{ Sig. } & \multicolumn{2}{|c|}{ Collinearity Statistics } \\
\hline & B & $\begin{array}{l}\text { Std. } \\
\text { Error }\end{array}$ & & & & Tolerance & VIF \\
\hline (Constant) & 59,558 & 45,497 & & 1,309 &, 200 & & \\
\hline ROI & 3,111 & 3,671 & ,217 & ,847 & ,403 & ,464 & 2,154 \\
\hline MBVE & ,000 & ,003 &,- 025 & -139 & 890 & 920 & 1,087 \\
\hline $\mathrm{ROA}$ & $-3,489$ & 5,721 &,- 153 &,- 610 &, 546 & ,485 & 2,060 \\
\hline
\end{tabular}


Uji hipotesis ke-1(d) atau $H_{1}(d)$

Hipotesis ke-1(d) menyatakan bahwa cost politic tidak mempengaruhi kebijakan dividen tunai. Berdasarkan hasil perhitungan uji t yang ditunjukkan pada tabel 4.12, diketahui bahwa ROA memiliki nilai $t$ hitung sebesar $-0,610$ dengan tingkat signifikasi 0,546 , yang lebih besar dibanding 0,05. Maka dapat disimpulkan bahwa $\mathrm{Ha}$ ditolak, yang berarti secara parsial tidak terdapat pengaruh yang signifikan antara cost politic terhadap kebijakan dividen tunai.

\section{Uji hipotesis ke-2(a) atau H2(a)}

Hipotesis ke-2(a) menyatakan bahwa likuditas sebagai variabel moderasi tidak mempengaruhi hubungan profitabilitas, investment oportunity set dan cost politic terhadap kebijakan dividen tunai. Berdasarkan hasil perhitungan uji $\mathrm{F}$ yang ditunjukkan pada tabel 4, diketahui bahwa model atau persamaan ke-2 memiliki nilai $\mathrm{F}$ sebesar 0,723 dengan tingkat signifikansi sebesar 0,634 yang lebih besar dibanding 0,05, maka dapat disimpulkan bahwa $\mathrm{Ha}$ ditolak, yang berarti secara simultan atau bersamasama tidak terdapat pengaruh yang signifikan antara likuiditas sebagai variabel moderasi dengan profitabilitas dan investment oportunity set terhadap kebijakan dividen tunai.

Tabel 4. Hasil Perhitungan Uji F (Secara Simultan) Dengan Variabel Moderasi

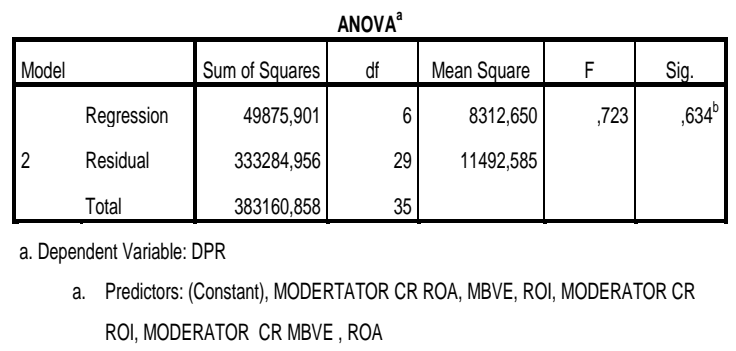

\section{Uji hipotesis ke-2(b) atau H2(b)}

Hipotesis ke-2(b) menyatakan bahwa likuditas sebagai variabel moderasi mempengaruhi hubungan profitabilitas terhadap kebijakan dividen tunai.
Berdasarkan hasil perhitungan uji $\mathrm{t}$ yang ditunjukkan pada tabel 5, diketahui bahwa CR.ROI memiliki nilai $\mathrm{t}$ hitung sebesar 1,558 dengan tingkat signifikasi 0,130 , yang lebih besar dibanding 0,05. Maka dapat disimpulkan bahwa $\mathrm{Ha}$ ditolak, yang berarti secara parsial tidak terdapat pengaruh yang signifikan antara likuiditas sebagai variabel moderasi dengan cost politic terhadap kebijakan dividen tunai.

Tabel 5. Hasil analisis regresi

\begin{tabular}{|c|c|c|c|c|c|c|c|}
\hline \multirow[t]{2}{*}{ Model } & \multicolumn{2}{|c|}{$\begin{array}{c}\text { Unstandardized } \\
\text { Coefficients }\end{array}$} & \multirow{2}{*}{ 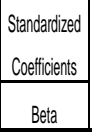 } & \multirow[t]{2}{*}{$t$} & \multirow[t]{2}{*}{ Sig. } & \multicolumn{2}{|c|}{ Collinearity Statisicics } \\
\hline & B & Std. Error & & & & Tolerance & VIF \\
\hline (Constant) & 65,769 & 49,781 & & 1,321 & 197 & & \\
\hline ROl & $-7,230$ & 7,288 & .504 & .992 & 329 & ,116 & 8,612 \\
\hline MBVE & 001 &, 006 &, 102 & 221 & 826 & , 142 & 7,023 \\
\hline $2 \mathrm{ROA}$ & 21,767 & 15,377 &, 952 & 1,416 &, 168 & 066 & 15,090 \\
\hline MODERATOR CR ROI & 091 & ,059 & 983 & 1,558 &, 130 & 075 & 13,288 \\
\hline MODERATOR CR MBVE & $\begin{array}{r}-3,764 E- \\
006\end{array}$ &, 000 & ;,091 & \begin{tabular}{|l|}
-172 \\
\end{tabular} &, 864 &, 107 & 9,305 \\
\hline MODERTATOR CRROA & -223 & 124 & $-1,453$ & $-1,799$ &, 082 & 046 & 21,729 \\
\hline
\end{tabular}

Uji hipotesis ke-2(c) atau $\mathrm{H} 2(\mathrm{c})$

Hipotesis ke-2(c) menyatakan bahwa likuiditas sebagai variabel moderasi mempengaruhi hubungan investment oportunity set terhadap kebijakan dividen tunai. Berdasarkan hasil perhitungan uji t yang ditunjukkan pada tabel 4.14, diketahui bahwa CR.MBVE memiliki nilai $\mathrm{t}$ hitung sebesar -0,172 dengan tingkat signifikasi sebesar 0,864 , yang lebih besar dibanding 0,05. Maka dapat disimpulkan bahwa Ha ditolak, yang berarti secara parsial tidak terdapat pengaruh yang signifikan antara likuiditas sebagai variabel moderasi dengan investment oportunity set terhadap kebijakan dividen tunai.

\section{Uji hipotesis ke2(d) atau H2(d)}

Hipotesis ke-2(c) menyatakan bahwa likuiditas sebagai variabel moderasi tidak mempengaruhi hubungan cost politic 
terhadap kebijakan dividen tunai. Berdasarkan hasil perhitungan uji t yang ditunjukkan pada tabel 4.14, diketahui bahwa CR.ROA memiliki nilai t hitung sebesar -1,799 dengan tingkat signifikasi 0,82 , yang lebih besar dibanding 0,05 . Maka dapat disimpulkan bahwa $\mathrm{Ha}$ ditolak, yang berarti secara parsial tidak terdapat pengaruh yang signifikan antara likuiditas sebagai variabel moderasi dengan leverage terhadap kebijakan dividen tunai.

\section{PEMBAHASAN}

Hipotesis ke-1(a) dalam penelitian ini menyatakan bahwa profitabilitas yang diproksikan dalam return on Invements, investment oportunity set yang diproksikan dalam market book value of equity dan cost politic yang diproksikan dengan return on asset tidak mempengaruhi kebijakan dividen tunai yang diproksikan dalam dividend payout ratio. Hubungan antar masing-masing variabel secara singkat dapat dijelaskan bahwa kebijakan dividen tidak tergantung pada profitabilitas, kesempatan investasi, dan cost politic. Kebijakan dividen merupakan keputusan yang diambil perusahaan atas alokasi laba perusahaan yaitu dibagikan untuk dividen atau ditahan untuk dana investasi, pada perusahaan plat merah menurut hasil penelitian ini besar kecilnya pembagian dividen tidak tergantung pada besar kecilnya laba bersih yang diperoleh perusahaan dan besar kecilnya dana yang dibutuhkan perusahaan sebagai dana investasi.

Berdasarkan hasil penelitian dapat disimpulkan bahwa secara simultan, hubungan variabel profitabilitas yang diproksikan dalam return on invesment dan variabel investment oportunity set yang diproksikan dalam market book value of equity dan cost politic yang diproksikan dengan return on asset tidak memiliki pengaruh yang signifikan terhadap perubahan variabel kebijakan dividen tunai yang diproksikan dalam dividend payout ratio. Hasil penelitian ini menunjukkan bahwa naik turunnya dividen tunai suatu perusahaan BUMN tidak dipengaruhi oleh perubahan atau fluktuasi nilai profitabilitas, nilai investment oportunity set dan nilai cost politic. Ini dapat terjadi karena antara profitabilitas, investment oportunity set (kesempatan investasi), cost politic dan kebijakan dividen tunai tidak saling berhubungan dan tidak memiliki keterkaitan yang dapat saling mempengaruhi sehingga dapat merubah keadaan bila diaplikasikan secara bersama-sama. Model regresi dalam penelitian ini dapat diterapkan dalam praktek kebijakan dividen pada suatu perusahaan. Hipotesis ini tidak mendukung penelitian-penelitian sebelumnya.

\section{Analisis pengaruh profitabilitas (ROI) terhadap kebijakan dividen tunai (DPR)}

Hipotesis ke-1(b) dalam penelitian ini menyatakan bahwa profitabilitas yang diproksikan dalam return on invesment berpengaruh negatif terhadap kebijakan dividen tunai yang diproksikan dalam dividend payout ratio. Return on invesment merupakan perbandingan laba bersih setelah pajak dengan total aktiva, yang mencerminkan kemampuan perusahaan dalam memanfaatkan total aset yang dimiliki perusahaan dalam menghasilkan laba bersih. Sedangkan kebijakan dividen tunai diproksikan menggunakan dividend payout ratio yang dihitung dengan perbandingan dividen kas tahunan dengan pendapatan dividen per lembar dari laba bersih perusahaan. Rasio ini mencerminkan besarnya dividen per lembar saham yang diterima oleh pemegang saham dari besarnya pendapatan dividen yang menjadi hak pemegang saham atas laba bersih perusahaan. Maka dividen yang dibagikan kepada pemegang saham 
bergantung pada besarnya laba bersih yang diperoleh perusahaan. Laba bersih yang diperoleh perusahaan dalam penelitian ini diproksikan dalam return on assets. Semakin tinggi laba bersih yang diperoleh perusahaan maka semakin tinggi besarnya dividen yang dibagikan kepada pemegang saham, sehingga semakin tinggi nilai return on assets maka nilai dividend payout ratio yang diperoleh cenderung semakin tinggi.

Berdasarkan hasil uji hipotesis, nilai koefisien regresi ROI memiliki nilai negatif yang menerangkan hubungan yg berlawanan antara ROI dengan DPR, yang artinya apabila ROI meningkat maka DPR akan turun. Namun hal ini tidak didukung dengan nilai signifikansi yang ada, sehingga dapat disimpulkan bahwa profitabilitas dalam penelitian ini tidak berpengaruh signifikan pada kebijakan dividen tunai. Berdasarkan data nilai ROI diketahui bahwa perubahan nilai ROI tidak seiring dengan perubahan nilai DPR, salah satu contoh Bank BNI, pada tahun 2015 - 2016 prosentase perubahan ROI mengalami kenaikan sebesar $10 \%$ sedangkan DPR justru naik sebesar $69 \%$. Pada tahun 2016 ke tahun 2017 ROI naik sebesar 6\% sedangkan DPR naik sebesar 30,3\%, kondisi ini juga terjadi pada perusahaan sampel yang lainnya. Hal ini dapat diakibatkan karena faktor-faktor lain dalam kebijakan dividen. Seperti yang dijelaskan sebelumnya bahwa kebijakan dividen juga dipengaruhi oleh beberapa faktor diantaranya tingkat likuiditas perusahaan, kesempatan investasi yang dimiliki, kebutuhan dana perusahaan di masa depan yang juga mempengaruhi besar kecilnya pembagian dividen. Dalam penelitian ini, kemungkinan kebijakan dividen tunai yang diterapkan perusahaan tidak dapat dipengaruhi oleh faktor profitabilitas saja, namun juga perlu didukung dengan faktor-faktor lain tersebut. Selain itu faktor politik juga dapat menyebabkan profitabilitas tidak mempengaruhi kebijakan dividen. .Hasil penelitian ini bertolak belakang dengan penelitian yang dilakukan sebelumnya

\section{Analisis pengaruh investment oportunity set (MBVE) terhadap kebijakan dividen tunai (DPR)}

Hipotesis ke-1(c) dalam penelitian ini menyatakan bahwa, investment oportunity set yang diproksikan dalam market book value of equity berpengaruh terhadap kebijakan dividen tunai yang diproksikan dalam dividend payout ratio. Market book value of equity merupakan perbandingan antara nilai pasar ekuitas dan nilai buku ekuitas, dimana menurut Sunarto (2004) menyatakan bahwa market to book value of equity mencerminkan bahwa pasar menilai return dari investasi perusahaan di masa depan dari return yang diharapkan dari ekuitasnya. Maka semakin besar nilai pasar dibanding nilai buku ekuitasnya, berarti perusahaan memiliki kemampuan yang tinggi dalam mengelola modal yang dimilikinya, yang mencerminkan bahwa perusahaan akan cenderung memiliki prospek yang baik di masa yang akan datang. Perusahaan yang memiliki prospek yang bagus cenderung memiliki pilihan investasi di masa yang akan datang. Pilihan investasi tersebut dapat menjadi kesempatan investasi yang menghasilkan keuntungan di masa depan jika perusahaan dapat menganalisa dan mengeksploitasi pilihan investasi tersebut. Jadi kesempatan investasi yang akan menghasilkan keuntungan di masa depan bergantung pada keputusan yang diambil perusahaan. Maka semakin besar kesempatan investasi yang dimiliki perusahaan, akan berakibat semakin besarnya alokasi laba untuk reinvestasi dan akan mengurangi jumlah alokasi laba yang digunakan untuk pembayaran dividen yang diharapkan.Walaupun jumlah dividen yang akan dibagi dapat berkurang akibat kebutuhan dana 
investasi, namun investor juga dapat merasakan hasil dari penggunaan dana investasi tersebut di masa yang akan datang, karena investasi saat ini akan menaikkan nilai pasar perusahaan di masa depan, sehingga investor akan mendapat nilai capital gain (selisih harga beli dengan harga jual) yang tinggi.

Hasil uji hipotesis dalam penelitian ini, menyatakan bahwa investment oportunity set yang diproksikan dalam MBVE tidak memiliki pengaruh yang signifikan terhadap kebijakan dividen tunai yang diproksikan dalam DPR. Hal ini dapat dibuktikan dengan analisa data yang terdapat pada tabel 4.12 signifikansi sebesar 0,890 dan data hasil perhitungan nilai MBVE pada PT Adhi Karya, PT Gas Negara mengalami penurunan dari tahun 2015 sampai 2016, nilai DPRnya justru mengalami kenaikam sebesar $67 \%$ pada PT Adhi Karya, dan sebesar 13,1\% pada PT Gas Negara. Pada tahun 2017 ke 2018 PT Gas Negara dan Semen Gresik nilai MBVE naik namun nilai DPR mengalami penurunan, akan tetapi secara umum fluktuasi perubahan nilai MBVE tidak seiring dengan fluktuasi nilai DPR. Hal ini menunjukkan bahwa kesempatan investasi tidak berpengaruh pada pembagian deviden tunai.

\section{Analisis pengaruh likuiditas (CR) sebagai variabel moderasi pada profitabilitas (ROI), investment oportunity set (MBVE) dan Cost Politic (ROA) terhadap kebijakan dividen tunai (DPR)}

Hipotesis ke-2(a) dalam penelitian ini menyatakan bahwa likuiditas yang diproksikan dalam current ratio sebagai variabel moderasi mempengaruhi hubungan profitabilitas yang diproksikan dalam return on invesment, investment oportunity set yang diproksikan dalam market book value of equity dan cost politic yang diproksikan dalam ROA akan mempengaruhi kebijakan dividen tunai yang diproksikan dalam dividend payout ratio. Hubungan antar masingmasing variabel sama dengan penjelasan pada poin-pain sebelumnya. Dimana secara singkat dapat dijelaskan bahwa kebijakan dividen tergantung pada profitabilitas dan kesempatan investasi, kebijakan dividen merupakan keputusan yang diambil perusahaan atas alokasi laba perusahaan yaitu dibagikan untuk dividen atau ditahan untuk dana investasi, besar kecilnya pembagian dividen tergantung pada besar kecilnya laba bersih yang diperoleh perusahaan dan besar kecilnya dana yang dibutuhkan perusahaan sebagai dana investasi. Jika dalam hubungan tersebut ditambah likuiditas sebagai variabel moderasi, maka diharapkan potensi likuiditas dapat mempengaruhi hubungan tersebut sehingga pembagian dividen dapat meningkat.

Berdasarkan hasil penelitian dapat disimpulkan bahwa secara simultan atau bersama-sama likuiditas sebagai variabel moderasi yang diproksikan dalam current ratio tidak mempengaruhi hubungan variabel profitabilitas yang diproksikan dalam return on invesment, variabel investment oportunity set yang diproksikan dalam market book value of equity dan cost politic yang diproksikan dalam ROA tidak memiliki pengaruh yang signifikan terhadap perubahan variabel kebijakan dividen tunai yang diproksikan dalam dividend payout ratio. Sehingga model regresi dalam penelitian ini dapat diterapkan dalam praktek kebijakan dividen pada suatu perusahaan. Hal ini tidak sebelumnya yang menyatakan bahwa profitabilitas berpengaruh pada kebijakan dividen tunai dengan likuiditas sebagai variabel moderasi. Dan pada variabel investment oportunity set sesuai dengan penelitian yang dilakukan oleh Suharli (2007) yang menyatakan bahwa variabel IOS tidak berpengaruh pada DPR . 
Analisis pengaruh likuiditas (CR) sebagai variabel moderasi pada hubungan profitabilitas (ROI) terhadap kebijakan dividen tunai (DPR)

Hipotesis ke-2(b) dalam penelitian ini menyatakan bahwa likuiditas sebagai variabel moderasi yang diproksikan dalam current ratio mempengaruhi hubungan profitabilitas yang diproksikan dalam return on invesment terhadap kebijakan dividen tunai yang diproksikan dalam dividend payout ratio. Pada penelitian ini menunjukkan hasil bahwa hipotesis tersebut tidak diterima, yang artinya tidak ada pengaruh yang significan antara profitabilitas dan DPR yang dimoderasi oleh likuiditas.

Berdasarkan hasil uji hipotesis, dengan masuknya variabel likuiditas sebagai variabel moderasi dalam model persamaan, sebetulnya mampu mempengaruhi hubungan profitabilitas terhadap kebijakan dividen. Karena dengan masuknya likuiditas pada persamaan nilai koefisien determinasi naik dari $2,7 \%$ menjadi $13 \%$ akan tetapi nilai koefisien determinasi tersebut masih rendah karena dibawah 50\% sehingga secara umum tidak berpengaruh secara signifikan ketiga variabel independent terhadap variabel dependent. hubungan ROA terhadap DPR tetap sama seperti sebelum adanya $\mathrm{CR}$, yaitu ROA tidak mempengaruhi DPR. Maka dapat disimpulkan bahwa naik turunnya likuiditas perusahaan tidak mempengaruhi pembagian dividen yang dipengaruhi oleh profitabilitas perusahaan. Hal ini dilihat dari perubahan nilai ROA dari tahun ke tahun selama periode pengamatan kenaikan atau penurunannya tidak seiring dengan kenaikan atau penurunan DPR.. Hal ini terjadi karena kemampuan likuiditas yang dimiliki perusahaan dimanfaatkan untuk kepentingan lain, misalnya untuk memenuhi kewajiban jangka pendek seperti pelunasan hutang ataupun untuk mendanai operasional perusahaan, dan bukan untuk kepentingan pembayaran dividen kepada para pemegang saham. Maka dapat disimpulkan bahwa likuiditas yang diproksikan dalam cash ratio kurang bisa diandalkan untuk dijadikan variabel moderasi dalam hubungan profitabilitas terhadap kebijakan dividen tunai yang diterapkan oleh perusahaan sampel pada penelitian ini. Hasil penelitian ini tidak mendukung hasil penelitian yang dilakukan oleh Suharli (2007) yang menyatakan bahwa likuiditas memperkuat hubungan profitabilitas terhadap kebijakan dividen. Dimana dalam penelitian yang dilakukan oleh Suharli (2007) derajat kepercayaan yang dipakai adalah sebesar $90 \%(<0,10$ sebagai syarat nilai signifikansi penelitian), sedangkan penelitian ini menggunakan derajat kepercayaan sebesar $95 \%(<0,05$ sebagai syarat nilai signifikansi penelitian). Kemungkinan karena besarnya derajat kepercayaan yang dipilih oleh Suharli (2004) lebih besar maka likuiditas dapat diterima sebagai variabel moderasi dalam hubungan antara profitabilitas dan kebijakan dividen tunai.

Analisis pengaruh likuiditas (CR) sebagai variabel moderasi pada hubungan investment oportunity set (MBVE) terhadap kebijakan dividen tunai (DPR)

Hipotesis ke-2(c) dalam penelitian ini menyatakan bahwa likuiditas sebagai variabel moderasi yang diproksikan dalam cash ratio tidak mempengaruhi hubungan investment oportunity set yang diproksikan dalam market book value of equity terhadap kebijakan dividen tunai yang diproksikan dalam dividend payout ratio. Hubungan market book value of equity dan dividend payout ratio yaitu market book value of equity secara singkat sesuai yang telah dijelaskan pada poin sebelumya yaitu market book value of equity diperoleh dari perbandingan nilai pasar dan nilai buku ekuitas, jika 
nilai pasar lebih tinggi dibanding nilai buku maka mencerminkan bahwa perusahaan memiliki prospek baik di masa yang akan datang, dimana perusahaan yang memiliki prospek yang baik cenderung memiliki pilihan untuk investasi di masa yang akan datang. Pilihan investasi tersebut dapat menjadi kesempatan investasi yang menghasilkan keuntungan di masa yang akan datang jika perusahaan mampu menganalisa dan mengeksploitasi pilihan investasi tersebut. Jika perusahaan ingin memanfaatkan kesempatan investasi tersebut akan memerlukan biaya investasi cukup besar, sedangkan dividend payout ratio merupakan rasio yang mencerminkan pembayaran dividen per lembar saham dari total pendapatan dividen yang diperoleh dari laba bersih yang diperoleh perusahaan. Dilihat dari rumus current asset dapat mencerminkan bahwa ketersediaan aset lancar yang melebihi hutang lancar menunjukkan tingkat dividen yang mampu dibagikan oleh perusahaan. Namun jika likuiditas digunakan sebagai variabel moderasi dalam hubungan investment oportunitty set dengan kebijakan dividen, maka akan memperlemah hubungan tersebut. Sebab adanya investment oportunity set (kesempatan investasi) akan mengurangi jumlah dividen yang dibagi, namun apabila perusahaan memiliki tingkat likuiditas yang tinggi maka pengaruh negatif dari investment oportunity set akan berkurang sehingga besarnya dividen yang dibagikan akan meningkat.

Berdasarkan hasil uji hipotesis, investment oportuniy set yang dimoderasi oleh likuiditas tidak mempengaruhi kebijakan deviden tunai karena nilai signifikansi sebesar 0,864 lebih besar dari 0,05, Hal ini terjadi karena tingkat likuiditas yang dimiliki perusahaan dimanfaatkan untuk kepentingan lain, misalnya untuk memenuhi kewajiban jangka pendek seperti pelunasan hutang ataupun untuk mendanai operasional perusahaan, dan bukan untuk kepentingan pembayaran dividen kepada para pemegang saham maupun untuk kepentingan investasi di masa yang akan datang. Maka dapat disimpulkan bahwa likuiditas yang diproksikan dalam current ratio kurang bisa diandalkan untuk dijadikan variabel moderasi dalam hubungan antara investment oportunity set terhadap kebijakan dividen tunai yang diterapkan oleh perusahaan sampel pada penelitian ini. Hasil penelitian ini mendukung hasil penelitian yang dilakukan oleh Suharli (2007), dengan hasil penelitian yang menunjukkan bahwa profitabilitas saja yang yang mempengaruhi kebijakan dividen tunai dengan diperkuat oleh likuiditas sebagai variabel moderasinya, sedangkan investment oportunity set tidak mempengaruhi kebijakan dividen tunai.

\section{Analisis pengaruh likuiditas (CR) sebagai variabel moderasi pada hubungan cost politic terhadap kebijakan dividen tunai (DPR)}

Hipotesis ke-2(d) dalam penelitian ini menyatakan bahwa likuiditas sebagai variabel moderasi yang diproksikan dalam cash rasio mempengaruhi hubungan cost politic yang diproksikan dalam return on asset terhadap kebijakan deviden tunai yang diproksikan dalam DPR tidak diterima. Pada penelitian ini proporsi laba bersih terhadap aktiva dalam biaya politik tidak berpengaruh signifikan terhadap kebijakan deviden tunai, hal ini dapat dilihat pada hasil pengujian pada tabel 4.14 hal 94 dimana nilai signifikansinya sebesar 0,086 lebih besar dari 0,05.

Berdasarkan hasil perhitungan nilai ROA secara umum menunjukkan bahwa kenaikan atau penurunan ROA selama periode penelitian tidak seiring dengan kenaikan atau penurunan DPR..Hal ini disebabkan karena faktor laba bersih atas aktiva perusahaan tidak 
digunakan untuk pembayaran deviden. Hasil penelitian ini tidak mendukung hasil penelitian yang dilakukan sebelumnya.

\section{KESIMPULAN DAN SARAN}

\section{Simpulan}

Berdasarkan hasil analisis diatas dapat disimpulkan bahwa :

a. Secara simultan profitabilitas, investment portunity set dan cost politic tidak berpengaruh secara signifikan terhadap kebijakan dividen tunai. Hal ini disebabkan karena variabel profitabilitas, investment oportunity set dan cost politic tidak saling berkaitan dan tidak memiliki keterkaitan satu sama lain sehingga pada saat bersama-sama kedua variabel ini tidak berpengaruh terhadap kebijakan dividen tunai.

b. Secara parsial profitabilitas tidak berpengaruh pada kebijakan dividen tunai.

c. Secara parsial investment oportunity set tidak berpengaruh significan pada kebijakan dividen tunai.

d. Secara simultan likuiditas sebagai variabel moderasi tidak mampu mempengaruhi hubungan profitabilitas, investment oportunity set dan cost politic terhadap kebijakan dividen tunai. Hal ini menunjukkan bahwa profitabilitas, investment oportunity set dan cost politic tidak memiliki hubungan dan keterkaitan yang apabila digunakan bersama-sama akan mempengaruhi kebijakan dividen, dan diperkuat oleh likuiditas yang dimiliki perusahaan.

e. Secara parsial likuiditas sebagai variabel moderasi tidak mempengaruhi hubungan antara profitabilitas terhadap kebijakan dividen tunai..

f. Secara parsial likuiditas sebagai variabel moderasi tidak mempengaruhi hubungan antara investment oportunity set terhadap kebijakan dividen tunai..

g. Secara parsial likuiditas sebagai variabel moderasi tidak mempengaruhi hubungan antara cost politik terhadap kebijakan dividen tunai.

\section{Saran}

a. Bagi praktisi (manajemen perusahaan), hasil penelitian ini diharapkan dapat menjadi bahan pertimbangan dalam mengambil keputusan kebijakan dividen yang menyangkut jumlah pembayaran dividen pada pemegang saham dan dapat memberikan informasi yang baik bagi investor.

b. Bagi investor dalam melakukan investasi di bursa efek harap memperhatikan nilai IOS yang diukur dengan market to book value of equity, karena hasil penelitian ini menunjukkan bahwa kenaikan atau penurunan nilai saham juga mempengaruhi kenaikan atau penurunan nilai DPR.

c. Bagi peneliti selanjutnya, penelitian ini diharapkan mampu menjadi tambahan literatur pada penelitian selanjutnya. Peneliti selanjutnya diharapkan dapat menambahkan variabel lain yang dapat mempengaruhi variabel dependen misalnya pertumbuhan perusahaan dan menambah periode penelitian yang lebih banyak agar hasil yang diperoleh menjadi lebih valid dan dapat menggambarkan keadaan yang sesungguhnya.

\section{DAFTAR PUSTAKA}

Anugrah, Anthi Dwi Putriani. Analisis Pengaruh Investment Oportunity Set (IOS) Terhadap Return Saham Perusahaan Sektor Manufaktur. Universitas Gunadarma.

Asiah, Siti dkk. 2012. Metode Penelitian Untuk Ilmu Ekonomi. Surabaya : 
Universitas Wijaya Kusuma Surabaya.

Hayati, Zalina. Pengaruh Investment Oportunity Set, Profitability dan Corporate Finance Terhadap Kebijakan Dividen Pada Perusahaan Manufaktur Di Indonesia. Universitas Islam Indonesia.

Jannati, Attina. Pengaruh Profitabilitas, Leverage Dan Growth Terhadap Kebijakan Dividen. Universitas Siliwangi.

Kasanah, Uswatun. 2009. Analisis Pengaruh Investasi, Likuiditas, Profitabilitas Dan Ukuran Perusahaan Terhadap Kebijakan Dividen Payout Ratio Pada Perusahaan Yang Terdaftar Di Jakarta Islamic Index Tahun 20002004. Yogyakarta : Universitas Islam Negeri Sunan Kalijaga Yogyakarta.

Kholidyah, Rudi Pratono. 2014. Pengaruh Profitabilitas Dan Invesment Opportunity Set Terhadap Kebijakan Deviden Tunai Dengan Cash Ratio Sebagai Variabel Moderasi. Surabaya: Universitas Wijaya Kusuma Surabaya.

Kurniawan, Iwan. 2012. VariabelVariabel yang Mempengaruhi Kebijakan Pembayaran Dividen pada Perusahaan Industri Otomotif yang Terdaftar di Bursa Efek Indonesia. Malang: Universitas Brawijaya Malang.

Liza Kumala Elissya. 2012. Analisis Faktor-Faktor Yang Mempengaruhi Kebijakan Dividen Tunai. Surakarta: Universitas Sebelas Maret

Marlina, Lisa dan Clara Danica. 2008. Analisis Pengaruh Cash Position, Debt Equity Ratio dan Return On Assets Terhadap Dividend Payout Ratio. Sumatera: Universitas Sumatera Utara.
Moeljadi. 2007. Manajemen Keuangan. Jilid 1. Malang : Universitas Brawijaya Malang.

Nopratiwi, Agustina M.V. 2004. Analisis Korelasi Investment Oportunity Set Terhadap Return Saham (Pada Saat Pelaporan Keuangan Perusahaan). Yogyakarta : STIE YKPN Yogyakarta.

Palino, Novianty. 2012. Faktor-Faktor Yang Mempengaruhi Dividen Tunai Pada Perusahaan Manufaktur Yang Terdaftar Di Bursa Efek Indonesia. Makassar : Universitas Hasanuddin Makassar.

Prastowo, Dwi. D dan Rifka Juliaty. 2005. Analisis Laporan Keuangan. Edisi Kedua. Yogyakarta : Sekolah Tinggi Ilmu Manajemen YKPN.

Putri, Arie Pratania. 2011. Pengaruh Investment Oportunity Set Dan Profitabilitas Terhadap Return Saham Dan Kebijakan Dividen Pada Perusahaan Manufaktur Yang Terdaftar Di Bursa Efek Indonesia. Medan : Universitas Sumatera Utara. Sadalia, Isfenti dan Nurul Syari Syafitri Saragih. 2008. Pengaruh Profitability Dan Investment Oportunity Set Terhadap Dividen Tunai Pada Perusahaan Terbuka Di Bursa Efek Indonesia. Jurnal Manajemen Bisnis, Vol.1 No.3. Medan : Universitas Sumatera Utara.

Sartono, Agus. 1998. Manajemen Keuangan. Edisi Ketiga. BPFE Yogyakarta : Universitas Gajah Mada Yogyakarta.

Satwiko, Agung Galih dkk. 2005. Kebijakan Dividen Perusahaan yang Listing di Bursa Efek Jakarta (BEJ) : Besaran, Strategi dan Stabilitas Dividen. Jurnal Riset Akuntansi Indonesia Vol. 8 No. 1 Hal. 13-33. Yogyakarta : Ikatan Akuntansi Indonesia.

Sudana, I Made. 2011. Manajemen Keuangan Perusahaan Teori Dan 
Praktik. Surabaya : Penerbit Erlangga.

Suharli, Michell. 2004. Pengaruh Profitability Dan Investment Opoertunity Set Terhadap Dividen Tunai Dengan Likuiditas Sebagai Variabel Penguat. Surabaya: Universitas Kristen Petra Surabaya.

Sunarto. 2004. Analisis Pengaruh Kepemilikan Manajerial, Investment Oportunity Set, Return On Asset Dan Debt To Equity Ratio Terhadap
Dividend Payout Ratio. Semarang : Universitas Diponegoro.

Tjandra, Ronowati. 2005. Pengaruh Investment Oportunity Set (IOS) Terhadap Kebijakan Dividen Dengan Pemoderasi Pilihan Prosedur Akuntansi Pada Perusahaan Yang Go Public Di Bursa Efek Jakarta. Yogyakarta: STIE YKPN Yogyakarta.

Weston, Fred dkk. 1991. Manajemen Keuangan. Jakarta : Penerbit Erlangga. 